\title{
PENGARUH KONSENTRASI ASAM FORMIAT DAN WAKTU REAKSI PADA PROSES DELIGNIFIKASI METODE ORGANOSOLV DARI LIMBAH BATANG PISANG (Musa Parasidiaca)
}

\section{THE INFLUENCE OF FORMIC ACID CONCENTRATION AND REACTION TIME ON DELIGNIFICATION ORGANOSOLV METHODE OF BANANA STEM WASTE (Musa Parasidiaca)}

\author{
Ancastami $^{1}$, Edwin Azwar ${ }^{2}$, Lia Lismeri ${ }^{3}$, dan Ridwan Santoso 4 \\ Fakultas Teknik JurusanTeknik Kimia Universitas Lampung \\ E-mail: ancastamii@gmail.com
}

Dikirim 6 Juni 2020, Direvisi 10 Juli 2020; Disetujui 27 Juli 2020

\begin{abstract}
Abstrak: Limbah batang pisang merupakan salah satu biomassa terbesar di Indonesia yang memiliki kandungan lignoselulosa yang cukup tinggi yaitu selulosa 59\%, lignin 10\%, dan hemiselulosa 18\%. Delignifikasi merupakan proses pemisahan ikatan selulosa dengan lignin dan hemiselulosa. Pada penelitian ini dilakukan proses delignifikasi limbah batang pisang dengan metode organosolv dimana pelarut yang dipakai ialah asam formiat dengan konsentrasi $60 \%, 70 \%, 80 \%$ - berat dan katalis $\mathrm{H}_{2} \mathrm{O}_{2} 5 \%$-berat pada suhu $100^{\circ} \mathrm{C}$ selama 120,150 , dan 180 menit. Kemudian dilakukan analisis kadar lignoselulosa dan dikarakterisasi dengan uji FTIR dan SEM. Dari hasil analisis setelah proses delignifikasi, pelarut asam formiat dapat memisahkan ikatan lignoselulosa, didapatkan yield selulosa terbaik dengan menggunakan pelarut asam formiat $70 \%$ dengan waktu 180 menit didapatkan kadar selulosa sebanyak $59,55 \%$.
\end{abstract}

Kata kunci: asam formiat, batang pisang, delignifikasi.

Abstract: Banana stem waste is one of the largest biomass in Indonesia which has a high content of lignocellulose, such as cellulose 59\%, lignin 10\%, and hemicellulose 18\%. Delignification is the process of separating cellulose from lignin and hemicellulose.In this study the delignification process of banana stem waste was carried out by the organosolv method where the solvent used was formic acid with a concentration of 60\%, 70\%, 80\% - weight and 5\% H2O2-weight catalyst at a temperature of 1000C for 120, 150, and 180 minutes.The yield analysis of lignocelullose was done and characterized by FTIR and SEM.The results of the analysis after the delignification process show that formic acid solvents can separate lignocellulosic bonds.By using $70 \%$ formic acid solvent in 180 minutes obtained the best cellulose yield as much as $59.55 \%$.

Keywords: formic acid,banana steam, delignification

\section{PENDAHULUAN}

Indonesia merupakan salah satu negara agraris yang menghasilkan banyak produk dari bidang perkebunan.Salah satu hasil dari industri perkebunan di Indonesia adalah Pisang. Indonesia merupakan negara urutan ke lima di dunia sebagai negara dengan produksi pisang sebesar 3,6 juta ton. Perkembangan ketersediaan pisang di Indonesia menunjukkan peningkatan dari tahun 1993-2013 yaitu dari 12,56 kg/kapita pada tahun 1993 , menjadi $24,03 \mathrm{~kg} / \mathrm{kapita}$ pada tahun 2013 dengan rata-rata peningkatan sebesar $3,81 \%$ per tahun (Kementrian pertanian, 2014). Salah satu daerah penghasil pisang terbesar di Indonesia adalah Provinsi Lampung, dengan penghasilan $18,36 \%$ untuk Indonesia. Menurut data Badan Pusat Statistik Provinsi Lampung pada tahun 2010 - 2013 secara berturut-turut menghasilkan pisang sebesar 777.809, 687.761, 817.606, dan 984.298 ton per tahun (Kementrian pertanian, 2014).

Sebagian besar hasil produksi pisang di Indonesia dijadikan keripik pisang dengan aneka rasa. Hingga saat ini pemanfaatan produksi hanya pada buahnya saja. Sisa dari proses hasil produksi pisang akan menjadi 
limbah perkebunan. Salah satu limbah perkebunan yang kurang termanfaatkan yaitu batang pisang. Rahman (2006) menyatakan bahwa perbandingan bobot segar antara batang, daun, dan buah pisang berturut-turut $63 \%$, 14\%, dan 23\%. Limbah batang pisang adalah salah satu tanaman yang dapat dijadikan sumber alternatif biomassa. Kandungan selulosa yang cukup tinggi ini membuat batang pisang dapat digunakan sebagai bahan baku pembuatan selulosa. Pelepah batang pohon pisang memiliki kandungan lignin rendah $(5 \%)$, selulosa (50-64\%), hemiselulosa (20\%).

Selulosa merupakan suatu polisakarida yang terdiri atas satuan glukosa yang berbentuk rantai linier yang mempunyaiformula umum $\left(\mathrm{C}_{6} \mathrm{H}_{10} \mathrm{O}_{5}\right) \mathrm{n}$ dan tidak mudah larut dalam air (Pradana, 2017). Selulosa ini merupakan salah satu komponen

utama tanaman yang terdapat pada lignoselulosa bersama dengan komponen lainnya seperti hemiselulosadan lignin. Sehingga untuk mendapatkan serat selulosa tersebut diperlukan suatu perlakuan untuk memisahkannya dari komponen hemiselulosa dan lignin.

Untuk mendapatkan selulosa diperlukan beberapa tahap dalam memproses bahan baku yakni dengan cara isolasi selulosa atau delignifikasi. Proses delignifikasi memberika hasil yang cukup baik dalam pemisahan struktur lignoselulosa.

Terdapat beberapa metode dalam proses delignifikasi seperti delignifikasi dengan metode mekanik, kraf atau proses organosolv (Enny dkk,2009). Pemilihan metode dalam proses delignifikasi akan berpengaruh terhadap hasil lignoselulosa yang didapatkan. Poses delignifikasi secara organosolv mulai banyak dikembangkan oleh beberapa peneliti. Proses delignifikasi secara organosolv dapat menjadi metode alternatif karena dalam pelaksanaannya menggunakan pelarut organik sehingga lebih ramah lingkungan (Fatmayati, 2017). Selulosa yang dihasilkan dari poses delignifikasi dapat digunakan sebagai sumber biomassa dari limbah perkebunan seperti bahan baku pembuatan karboksimetil selulosa.

Oleh karena itu, penelitian ini dilakukan untuk memanfaatkan limbah batang pisang sebagai sumber selulosa.Hasil penelitian ini diharapkan dapat memberikan informasi baru dan kontribusi dalam pengembangan selulosadari batang pohon pisang

\section{A. Landasan Teori}

\section{Tanaman Pisang}

Indonesia merupakan salah satu negara agraris yang menghasilkan banyak produk dari bidang perkebunan. Salah satu hasil dari industri perkebunan di Indonesia adalah Pisang.

Pisang (musa paradisiaca) adalah nama umum yang diberikan pada tumbuhan berdaun besar memanjang dari suku Musaceae.

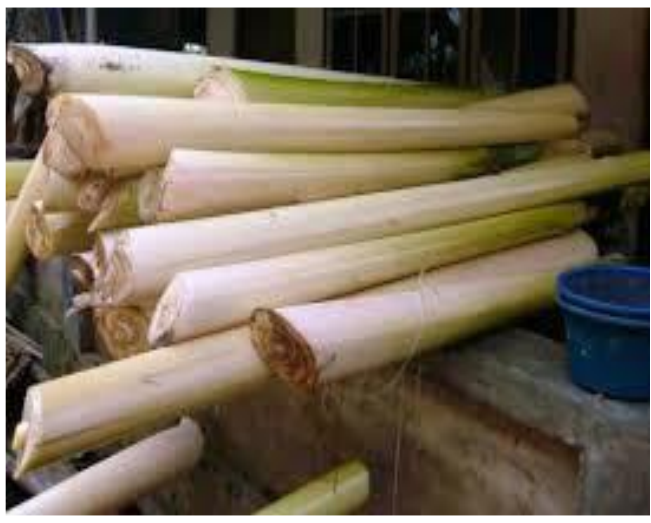

Gambar 1. Batang Pisang (Suharyani, 2012) 
Tanaman pisang (Musa paradisiaca) dapat dimanfaatkan mulai dari batang pisang bagian bawah (bongkol), tengah dan bagian atas termasuk daunnya. Menurut Santi (2012) total produksi batang pisang dalam berat segar minimum mencapai 100 kali lipat dari produksi buah pisangnya sedangkan total produksi daun pisang dapat mencapai 30 kali lipat dari produksi buah pisang. Tanaman pisang merupakan tanaman yang hanya berbuah sekali oleh karena itu setelah buah pisang dipanen, batang pisang akan dipotong dan dibuang karena tanaman pisang tidak bisa lagi dipanen sehingga akan menjadi limbah pertanian. Limbah batang pisang yang tidak terpakai lagi dapat dimanfaatkan menjadisuatu produk yang bernilai karena kandungan selulosanya yang tinggi (Hussain, 2014).

Batang pisang mengandung lebih dari $80 \%$ air dan memiliki kandungan selulosa yang tinggi sehingga dapat dimanfaatkan sebagai suatu sumber alternatif biomassa. Dalam batang pisang terdapat kandungan lignoselulosa seperti lignin, hemiselulosa, dan selulosa (Syamsul, 2015). Kandungan lignoselulosa tersebut utamanya diproduksi oleh tumbuhan untuk membentuk dinding sel dan berperan sebagai penyusun struktural (Idi and Muhmad, 2011).

\section{Komponen Struktur Lignoselulosa}

Bahan yang mengandung lignoselulosa merupakan biomassa yang berasal dari tanaman dengan komponen utama lignin, selulosa, dan hemiselulosa. Ketersediaannya yang cukup melimpah, terutama sebagai limbah pertanian. komposisi kimia batang pisang ditunjukkan pada tabel 1 dibawah ini.
Tabel 1. Komposisi Kimia Batang Pisang

\begin{tabular}{cc}
\hline $\begin{array}{c}\text { Komposisi } \\
\text { kimia }\end{array}$ & $\begin{array}{c}\text { Kandungan } \\
(\%)\end{array}$ \\
\hline Hemiselulosa & $6-8$ \\
Lignin & $5-10$ \\
Selulosa & $50-65$ \\
Air & $10-15$ \\
\hline
\end{tabular}

(sumber : Asparani, 2013)

\section{a. Hemiselulosa}

Hemiselulosa merupakan polisakarida yang mengisi ruang antara serat -serat selulosa dalam dinding sel sel tumbuhan. Hemiselulosa merupakan polimer dari sejumlah sakarida-sakarida yang berbeda-beda yaitu D-glukosa, L-arabinosa, $D$ silosa, D-glukorunat, susunan dari bahan-bahan tersebut di dalam rantai hemiselulosa sangat tidak teratur (Dewi, 2009).

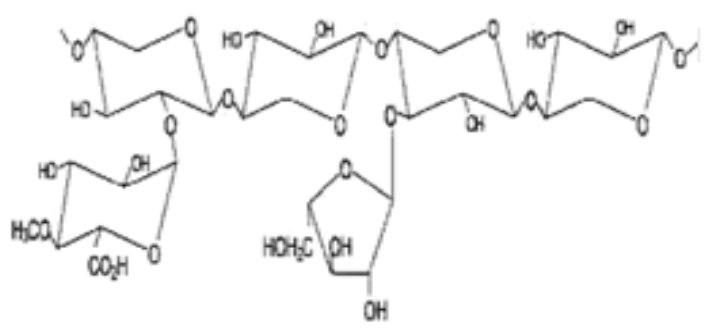

Gambar 2. Struktur Dasar Lignoselulosa Hemiselulosa (Parwati, 2014) 
Hemiselulosa bersama lignin membalut serta menyatukan serat-serat selulosa membentuk wujud tiga dimensi mengakibatkan struktur sel tanaman bersifat pasif dan kaku (Syamsul, 2015).

Hemiselulosa mempunyai rantai polimer yang pendek dan tak berbentuk, oleh karena itu sebagian besar dapat larut dalam air. Hemiselulosa mengikat lembaran serat selulosa membentuk mikrofibril yang meningkatkan stabilitas dinding sel. Hemiselulosa juga berikatan silang dengan lignin membentuk jaringan kompleks dan memberikan struktur yang kuat (Murni dkk., 2008)

\section{a. Lignin}

Lignin merupakan zat pengikat antara moleku - molekul selulosa (Susy, 2008). Lignin adalah polimer alami yang terdiri dari molekul-molekul polifenol yang berfungsi sebagai pengikat sel-sel kayu satu sama lain, sehingga kayu menjadi keras dan kaku. Lignin adalah polimer berkadar aromatik-fenolik yang tinggi, berwarna kecokelatan, dapat larut dalam larutan organik dan alkali encer (Dewi,2009). Didalam batang pisang lignin berikatan dengan selulosa sehingga untuk memperoleh selulosa maka kandungan lignin dalam tanaman harus dihilangkan.Proses penghilangan lignin ini disebut "proses delignifikasi" semakin rendah kandungan lignin suatu bahan, maka akan semakin baik hasilnya (Susy, 2008). Pada lignoselulosa terdapat lignin yang berperan sebagai pelindung selulosa terhadap serangan enzim pemecah selulosa. Komposisi kimia dan struktur yang demikian membuat bahan yang mengandung lignoselulosa bersifat kaku dan keras.

\section{b. Selulosa}

Selulosa merupakan polisakarida yang berbentuk linier yang tidak mudah larut dalam air (Pradana, 2017). Selulosa yang terkandung dalam batang pisang merupakan

senyawa polisakarida yang tidak mudah larut dalam air yang berfungsi sebagai pembentuk

sel kulit pada tanaman. Batang pisang memiliki kadar kandungan selulosa sekitar 50-65\% (Asparani,2013). Selulosa yang cukup tinggi dalam batang pisang dapat dijadikan sebagai bahan baku pembuatan selulosa. Selulosa akan larut dalam larutan asam dengan konsentrasi tinggi (akibat hidrolisis).

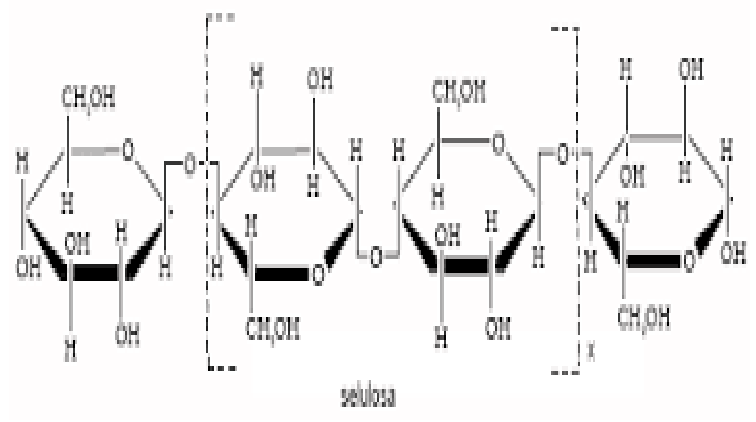

Gambar 3. Struktur selulosa (Susy, 2008)

Selulosa tidak pernah ditemukan dalam keadaan murni di alam, tetapi selalu berikatan dengan komponen lain seperti lignin dan hemiselulosa membentuk komponen lignoselulosa. Struktur berkristal serta adanya lignin dan hemiselulosa disekeliling selulosa merupakan hambatan utama dalam menghidrolisis selulosa (Muharni, 2016). Selulosa yang terkandung dalam batang pisang belum dalam keadaan murni melainkan masih berikatan dengan senyawa lignin dan hemiselulosa, sehingga perlu dilakukan suatu treatment permurnian untuk menghilangkan senyawa lignin dan hemiselulosa.

Selulosa tidak pernah ditemukan dalam keadaan murni di alam, tetapi selalu berikatan dengan komponen lain seperti lignin dan hemiselulosa membentuk 
komponen lignoselulosa. Struktur berkristal serta adanya lignin dan hemiselulosa disekeliling selulosa merupakan hambatan utama dalam menghidrolisis selulosa (Muharni, 2016). Selulosa yang terkandung dalam batang pisang belum dalam keadaan murni melainkan masih berikatan dengan senyawa lignin dan hemiselulosa, sehingga perlu dilakukan suatu treatment permurnian untuk menghilangkan senyawa lignin dan hemiselulosa.

\section{Delignifikasi}

Delignifikasi merupakan suatu proses pemutusan ikatan ignin dari struktur lignoselulosa. Delignifikasi bertujuan untuk mengurangi kadar lignin di dalam bahan berlignoselulosa. Delignifikasi akan membuka struktur lignoselulosa agar selulosa menjadi lebih mudah diakses. Proses delignifikasi akan melarutkan kandungan lignin di dalam bahan sehingga mempermudah proses pemisahan lignin dengan serat (Sumada, et. Al., 2011).

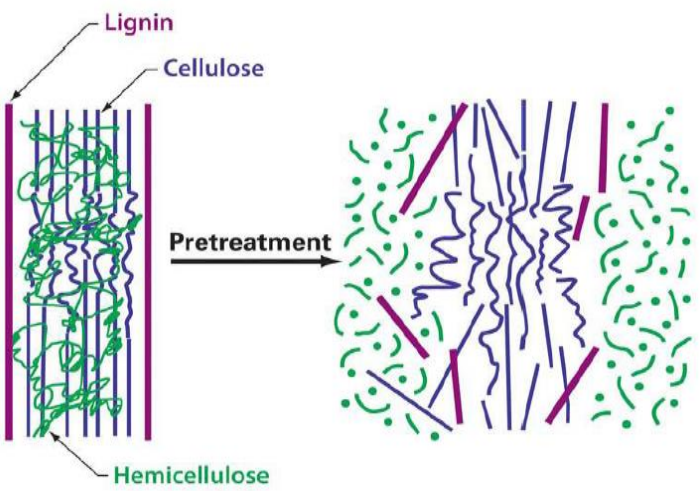

Gambar 4. Skema Pemisahan Bahan Lignoselulosa (Moiseretal., 2005)

Menurut Sun (2004), delignifikasi dikatakan baik seperti :

1. Dapat menghindari degradasi selulosa

2. Dapat menghindari pembentukan produk samping yang dapat menghambat proses hidrolisis. Ekonomis.
Untuk mendapatkan hasil yang baik pemilihan metode dalam proses delignifikasi akan berpengaruh terhadap hasil selulosa yang didapatkan.Agar hasil yang diperoleh optimal terdapat beberapa metode dalam proses delignifikasi seperti delignifikasi dengan metode mekanik, alkali atau proses organosolv (Dewi, 2009).

Delignifikasi dengan metode mekanik dilakukan tanpa menggunakan zat kimia. Proses ini dilakukan dengan menggunakan mesin tanpa adanya pereaksi kimia. Pada Proses ini bahan dihancurka seperti bubur didalam alat sehingga secara fisik serat akan rusak. Pembuatan selulosa secara mekanik memerlukan biaya yang besar, dikarenakan pada prosesnya tidak memakai pereaksi kimia untuk memisahkan kandungan dalam bahan. Selain itu proses mekanik dianggap lebih sulit daripada metode lainnya, sehingga proses ini jarang digunakan.

Pada delignifikasi metode alkali mekanisme utamanya adalah merusak

struktur lignoselulosa pada biomassa untuk meghilangkan hemiselulosa dan lignin sehingga yang tersisa selulosa untuk perlakuan selanjutnya. Hidrolisis alkali terjadi pada kondisi sedang (dibawah $140^{\circ}$ ). Metode alkali memiliki beberapa kelemahan yaitu harganya mahal dan pemutusan struktur lignin mengarah pada pemecahan ikatan glikosidiknya(Muladi, 2013). Larutan alkali dan temperatur yang terlalu tinggi juga dapat mengakibatkan penurunan kandungan selulosa dan hemiselulosa (Muladi, 2013). Pada proses delignifikasi inimenggunakan bahan yang relatif lebih banyak dan berbahaya.

Penggunaan air yang banyak juga perlu diperhatikan karena limbah yang dihasilkan harus dicairkan terlebih dahulu. Sehingga perlu dikembangkan suatu proses delignifikasi dengan menggunakan bahan 
yang ramah lingkungan dan mudah seperti proses organosolv.

\section{Delignifikasi Metode Organoslov}

Proses delignifikasi metode organosolv merupakan tahap pengurangan dan penghilangan kandungan lignin dan hemiselulosa pada komponen lignoselulosa dengan menggunakan pelarut organik seperti misalnya metanol, etanol, aseton, asam asetat, asam formiat dan lain-lain. Dewi (2009) menyatakan bahwa pemanfaatan biomassa secara efisien dapat dilakukan dengan menerapkan konsep biomass refining yaitu pemrosesan dengan menggunakan pelarut organik (organosolv processes), dengancara melakukan proses pemilahan biomassa menjadikomponenkomponen utama penyusunnya yaitu selulosa, hemiselulosa dan lignin, tanpa banyakmerusak ataupun mengubahnya . Proses organosolv memberikan beberapa keuntungan, antara lain yaitu rendemen pulp yang dihasilkan tinggi, tidak menimbulkan pencemaran gas berbau, tidak menggunakan unsur sulfur sehingga lebih aman terhadap lingkungan, karena menghasilkan limbah yang bersifat ramah

lingkungan (Dewi, 2009).

Delignifikasi selulosa dapat dilakukan menggunakan larutan organik seperti asam formiat sebagai larutan pemasak yang dapat digunakan pada suhu dan tekanan rendah, pada penambahan katalis ataupun tanpa katalis, serta harga yang relatif lebih murah. Pelarut pada proses organosolv yang banyak dikembangkan oleh peneleliti salah satunya adalah asam formiat. Asam formiat banyak diminati karena harganya yang murah, mudah digunakan, dapat digunakan pada suhu dan tekanan rendah (Zulfansyah, 2011).

Pada proses delignifikasi ada beberapa faktor yang mempengaruhi proses delignifikasi antara lain adalah waktu pemasakan, konsentrasi larutan pemasak, percampuran bahan, perbandingan larutan pemasak dengan bahan baku, ukuran bahan, suhu dan tekanan, dan konsentrasi katalis(Enny dkk, 2009).

\section{Asam Formiat}

Asam semut adalah asam karboksilat yang paling sederhana dengan nama lain asam format atau sering disebut asam formiat. Rumus molekul asam formiat adalah $\mathrm{HCOOH}$. Asam formiat merupakan pelarut yang banyak dikembangkan oleh para peneliti, karena asam formiat merupakan larutan yang mudah digunakan, murah dan ramah terhadap lingkungan.

Menurut zulfansyah, 2011 konsentrasi asam formiat merupakan variabel paling berpengaruh terhadap yield yang dihasilkan diikuti dengan waktu pemasakan dan kosentrasi katalis.Asam formiat digunakan untuk melarutkan bahan - bahan nonselulosa yang terdapat pada batang pohon pisang.

\section{Penelitian Terdahulu}

Sebelumnya telah dilakukan penelitian mengenai delignifikasi metode organoslov dan dari

penelitian- penelitian terdahulu inilah ditentukan variabel tetap pada penelitian ini.

Zulfansyah dkk (2011) menggunakan bahan dasar pelepah sawit yang sudah didelignifikasi menggunakan asam formiat dengan konsentrasi $65 \%, 75 \%, 85 \%$ - berat dan asam peroksida dengan konsentrasi $1 \%, 3 \%, 5 \%$-berat sebagai katalisator menyatakan dengan adanya peningkatan konsentrasi asam formiat berpengaruh positif pada penghilangan kadar lignin.

Sherly (2016) juga melakukan penlitian delignifikasi dengan media asam formiat dengan rumput perimping sebagai baha baku utama. Delignifikasi dilakukan menggunakan asam formiat dengan variasi 
konsentrasi $60 \%, 70 \%, 80 \%$ - berat dan waktu reaksi 60, 120, 180 menit. Konsentrasi asam formiat dan waktu reaksi merupakan kondisi proses yang berpengaruh terhadap yield dan penurunan kadar lignin. Kadar lignin terendah didapatkan pada konsentrasi asam formiat $80 \%$ dan waktu 180 menit.

Fatmayati (2017) melakukan penelitian delignifikasi batang sawit nonproduktif secara organosolv dengan pelarut asam formiat. Penelitian ini dilakukan dengan pelarut asam formiat $90 \%$ berat dengan variasi waktu reaksi 30, 60, 90, 120 menit didapatkan hasil terbaik pada waktu reaksi 120 menit dimana didapatkan perolehan kadar selulosa terbaik dengan kadar lignin rendah. Perlakuan peningkatan waktu reaksi delignifikasi memberikan pengaruh besar terhadap penurunan kadar lignin (Fatmayati,2017).

\section{A. METODOLOGI}

Metode Penelitian dilakukan secara beberapa tahapan sebagai berikut:

\section{Persiapan Bahan Baku}

Bahan yang digunakan pada penilitian ini adalah batang pisang yang berasal dari kebun pisang masyarakat sekitar Sukarame, Bandar Lampung, Lampung. Batang pohon pisang yang didapat dibersihkan dari pengotor - pengotornya. Batang pohon pisang yang sudah bersih dipotong - potong kemudian dijemur dibawah sinar matahari sampai kering. Batang pohon pisang kering kemudian digiling dan diayak menggunakan ayakan berukur 60 mesh. Kemudian tepung batang pisang dikeringkan kembali menggunakan oven pada suhu $105^{\circ} \mathrm{C}$ selama 2 jam.

\section{Penentuan Kadar Air}

Sebanyak 10 gram sampel serbuk batang pohon pisang diletakan dalam cawan petri yang telah dibersihkan, selanjutnya dimasukan ke dalam oven selama 2 jam pada suhu $105^{\circ} \mathrm{C}$ lalu ditimbang. Kemudian cawan beserta sampel dipanaskan kembali selama 1 jam hingga diperoleh berat konstan. Kadar air ditentukan dengan persamaan sebagai berikut :

$$
\begin{aligned}
& \text { kadar air }(\%)=\frac{\mathrm{B}-\mathrm{C}}{\mathrm{B}} \times 100 \% \\
& \text { Keterangan : } \\
& \mathrm{B}=\text { Berat } \\
& \text { dipampel } \\
& \begin{array}{l}
\mathrm{C}=\text { sebelum } \\
\text { dipanaskan }
\end{array}
\end{aligned}
$$

(SNI-04557-1998)

\section{Delignifikasi}

Serbuk batang pohon pisang yang diperoleh kemudian diisolasi selulosanya. Sebanyak 10 gram serbuk batang pohon pisang dimasukan dalam labu leher tiga dan ditambahkan larutan asam formiat dengan variasi konsentasi 60\%, 70\%, 80\%-berat dan hidrogen peroksida dengan konsentrasi 5\%-berat sebagai katalisator kemudian campuran dimasak selama 120, 150, 180 menit pada suhu $100^{\circ} \mathrm{C}$ Sambil diaduk. Kemudian selulosa yang didapatkan dipisahkan dari pelarut asam dan dicuci dengan aquades hingga netral. Setelah pencucian, selulosa basah selanjutnya dikeringkan menggunakan oven pada suhu $100^{\circ} \mathrm{C}$ selama 180 menit.

\section{Analisis produk}

Analisis pada produk meliputi uji kadar lignoseelulosa, SEM, dan FTIR.

\section{B. HASIL DAN PEMBAHASAN}

Dari hasil penelitian yang telah dilakukan mengenai pembuatan selulosa dari limbah batang pisang dengan proses delignifikasi metode organosolv menggunakan larutan organik asam formiat terjadi perubahan fisik pada bahan baku yang mengalami perubahan warna seperti pada gambar 5 . 


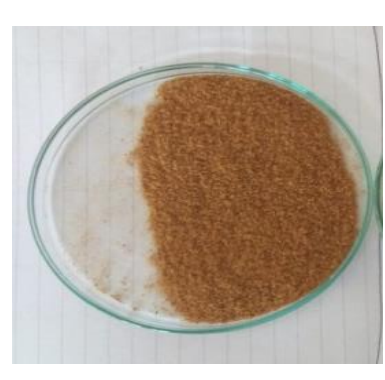

(a)

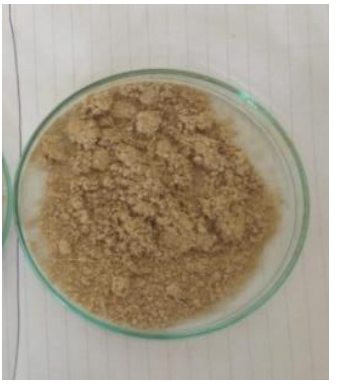

(b)
Gambar 5. Perubahan warna pada tahap delignifikasi selulosa (a) sebelum delignifikasi (b) sesudah delignifiikasi

.Pada gambar 5. Menunjukan penampilan fisik dari bahan baku yaitu batang pisang sebelum treatment berwarna coklat gelap. Setelah dilakukan proses delignifikasi terjadi perubahan warna menjadi lebih putih, hal ini disebabkan oleh hilangnya kandungan lignin dalam bahan yang terlarut dalam proses delignifikasi.

A. Pengaruh Larutan Pemasak dan Waktu Pemasakan Terhadap Proses Delignifikasi

Dari hasil yang telah dilakukan pengaruh variasi konsentrasi larutan pemasak dan waktu reaksi pemasakan dapat memberikan pengaruh terhadap perolehan kadar selulosa batang pisang, didapatkan kadar selulosa dengan berbagai konsentrasi pelarut seperti pada gambar 6 .

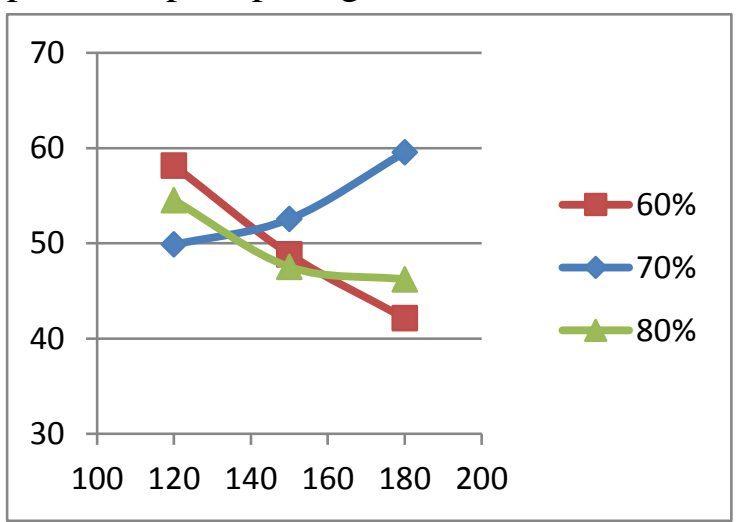

Gambar 6. Grafik hubungan waktu reaksi terhadap kadar selulosa
.Berdasarkan gambar 6. perolehan kadar selulosa pada konsentrasi $70 \%$ dengan lama waktu pemasakan cenderung naik seiring dengan semakin lamanya waktu pemasakan. Lamanya waktu reaksi pada proses delignifikasi menunjukan hasil dimana semakin lama waktu pemasakan maka akan semakin banyak rendemen lignin yang hilang dan meningkatkan kadar selulosa. Menurut Fatmayati (2017) peningkatan kadar selulosa terjadi karena semakin lamanya waktu kontak pelarut dengan struktur lignoselulosa di dalam bahan sehigga akan meningkatkan aksesibilitas selulosa dan proses penguraian lignin yang dilakukan oleh pelarut asam formiat juga semakin lama terjadi. Pada konsentrasi pelarut $60 \%$ menuju $70 \%$ terjadi kenaikan kadar selulosa seiring dengan semakin tingginya konsentrasi pelarut. Hal ini mengindikasikan bahwa semakin tinggi konsentrasi yang digunakan maka akan semakin banyak selulosa yang terbebas

dari ikatan lignoselulosa.Dimana hal ini mengakibatkan banyaknya ikatan lignin yang terlarut maka ikatan selulosa yang terbentuk pun semakin banyak. Penambahan konsentrasi asam juga dapat meningkatkan laju delignifikasi dan menghasilkan lebih banyak selulosa (Zhao et al, 2009). Peningkatan kandungan selulosa pada bahan merupakan hasil dari berkurangnya kadar hemiselulosa. Dimana hemiselulosa merupakan polimer yang heterogen dan bercabang dari pentose dan heksosa yang relative mudah terhidrolisis menjadi monomer - monomernya. Sedangkan, selulosa merupakan polimer kristalin yang tidak mudah terhidrolisis dengan bahan kimia.

Adanya penambahan 5\% - berat katalis $\mathrm{H} 2 \mathrm{O} 2$ dalam asam formiat memberikan pengaruh positif dalam tahap ini. Penambahan hidrogen peroksida dalam asam formiat akan membentuk asam peroksiformiat sehingga dapat 
mempercepat berlangsungnya proses delignifikasi dan melindungi selulosa dari hidrolisis asam formiat [Kham 2005].

Tabel 2. Kadar Lignoselulosa Batang Pisang

\begin{tabular}{|c|c|c|c|c|}
\hline $\begin{array}{l}\text { Konsen } \\
\text { trasi } \\
\text { Asam } \\
\text { Formiat } \\
(\%)\end{array}$ & $\begin{array}{c}\text { Wa } \\
\text { ktu } \\
\text { reaksi } \\
\text { (menit) }\end{array}$ & $\begin{array}{r}\text { Sel } \\
\text { ulow } \\
(\%)\end{array}$ & $\begin{array}{c}\text { Hemisel } \\
\text { uloqz } \\
\text { (\%) }\end{array}$ & $\begin{array}{l}\text { Lig } \\
\text { nin } \\
(\% \\
)^{\circ}\end{array}$ \\
\hline \multirow{2}{*}{$\begin{array}{l}\text { Bahan } \\
\text { Baku } \\
\text { Axal }\end{array}$} & - & $\begin{array}{c}13, \\
51\end{array}$ & 27,16 & $\begin{array}{c}14, \\
51\end{array}$ \\
\hline & 120 & $\begin{array}{c}58 \\
16\end{array}$ & 15,50 & $\frac{10}{7}$ \\
\hline \multirow[t]{2}{*}{$60 \%$} & 150 & $\begin{array}{l}48 \\
85\end{array}$ & 13,17 & $\begin{array}{l}27 \\
83\end{array}$ \\
\hline & 180 & $\begin{array}{c}42 \\
14\end{array}$ & 10,62 & $\begin{array}{c}32 \\
25\end{array}$ \\
\hline \multirow[t]{3}{*}{$70 \%$} & 120 & $\begin{array}{c}49 \\
86\end{array}$ & 12,83 & $\begin{array}{l}21 \\
01\end{array}$ \\
\hline & 150 & $\begin{array}{c}52 \\
55\end{array}$ & 2,53 & $\begin{array}{l}20 \\
83\end{array}$ \\
\hline & 180 & $\begin{array}{c}59 \text {, } \\
55\end{array}$ & 18,83 & $\begin{array}{l}10 \\
43\end{array}$ \\
\hline \multirow[t]{3}{*}{$80 \%$} & 120 & $\begin{array}{c}54, \\
52\end{array}$ & 16,87 & $\begin{array}{c}17 \\
56\end{array}$ \\
\hline & 150 & $\begin{array}{c}47 \\
53\end{array}$ & 16,71 & $\begin{array}{c}23 \\
45\end{array}$ \\
\hline & 180 & $\begin{array}{c}48 \\
22\end{array}$ & 21,38 & $\begin{array}{c}16 \\
79\end{array}$ \\
\hline
\end{tabular}

konsentrasi asam formiat ${ }^{1} 70 \%$ dengan waktu 180 menit sebesar $10,43 \%$. Penurunan kadar lignin mulai terjadi pada konsentrasi $70 \%$ - 80\% dengan lama waktu 150 - 180 menit. Meningkatnya konsentrasi larutan pemasak menimbulkan bertambahnya ion $\mathrm{H}^{+}$yang berperan dalam pemutusan ikatan lignin sehingga didaptkan selulosa yang lebik banyak terlepat dari ikatan lignoselulosanya (Fatmayati, 2017).

Variasi konsentrasi pemasak dan waktu reaksi memberikan pengaruh terhadap kadar lignin batang pisang. Dari hasil penelitian yang telah dilakukan hasil kadar lignin yang diperoleh cenderung terjadi proses penurunan terhadap lamanya waktu pemasakan.Lamanya waktu reaksi pada proses delignifikasi sangat berpengaruh dimana semakin lama waktu pemasakan maka semakin banyak rendemen lignin yang hilang dari bahan karena semakin lama terjadi kontak antara pelarut dengan bahan baku (biomassa) sehingga semakin banyak lignin yang ikut terlarut dalam pelarut yang digunakan. Semakin lama waktu pemasakan menyebabkan semakin sempurna larutan pemasak memenuhi rongga-rongga dalam bahan baku (penetrasi pelarut) sehingga degradasi lignin lebih banyak terjadi dan didaptkan selulosa yang murni (Yohana, 2015).

Namun pada waktu pemasakan yang terlalu lama akan mengakibatkan terjadinya degradasi senyawa penyusun lignin yangmenyebabkan ligninyang pada awalnya sudah terpisah dari bahan baku akibat lamanya waktu pemasakan biomassa dalam media pelarut akan menyebabkan terjadinya repolimerasi lignin (Amraini, 2010). Menurut Sherly (2016) faktor yang paling berpengaruh terhadap penurunan kadar lignin adalah waktu reaksi.

\section{B. Analisis Scaning Electron Microscopy (SEM)}

Struktur morfologi bahan dianalisis dengan scanning electron microscopy (SEM). Berdasarkan gambar 7. (a), batang pisang yang belum diberi perlakuan memiliki serat-serat yang saling berikatan dengan cukup rapat. Ikatan yang tidak beraturan tersebut menunjukkan ikatan antar lignoselulosa masih sangat rapat dan padat, hal ini disebabkan karena strukur lignin, hemiselulosa, dan selulosa yang masih terikat. 
(a)
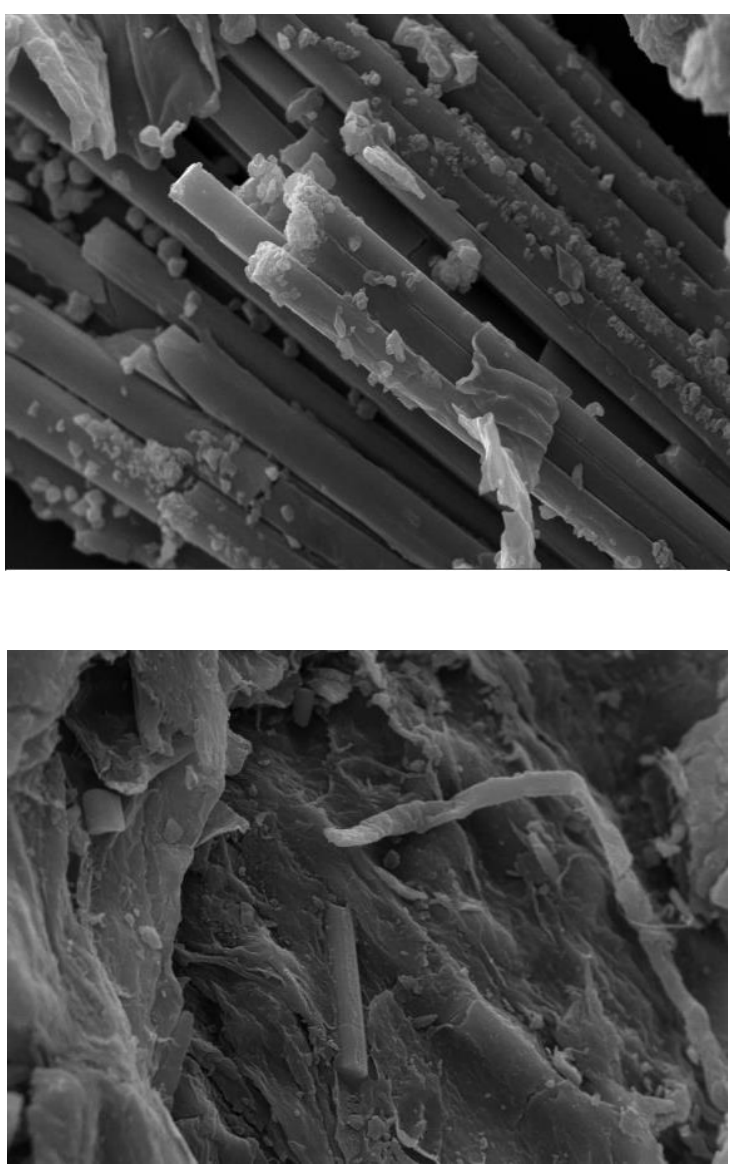

(b)

Gambar 7. (a) Hasil SEM batang pisang sebelum delignifikasi

(b) hasil SEM batang pisang setelah delignifikasi

Serat batang pisang setelah delignifikasi terjadi perbedaan permukaan serat dimana terlihat ikatan yang cukup renggang seperti pada gambar 7 (b). Sesudah adanya treatmen, struktu rpermukaan yang melindungi permukaan serat terlihat rusak dan tidak rapat. struktur permukaan serat terlihat renggang dan tidak rapat seperti sebelumnya karena dinding lignin yang menutupi mulai rusak dan hemiselulosa yang mengikat selulosa terpisah karena ikatan $\beta-1,4$ glikosida pada serat selulosa sudah dipecah dengan pelarut asam formiat. Hal ini menandakan bahwa larutan asam formiat cukup efektif digunakan untuk merenggangkan ikatan antara lignin, hemiselulosa, dan selulosa.

C. Ananlisis Fourier Transform Infrared (FTIR)

\section{Analisis Fourier Transform Infra} Red (FTIR) sering digunakan untuk mengetahui struktur utama dan perubahan kimia pada lignoselulosa dari biomassa selama proses percobaan. Pada Gambar 8. Terdapat perubahan puncak-puncakyang muncul antara batang pisang sebelum di delignifiksasi dengan batang pisang setelah delignifikasi.

(a)
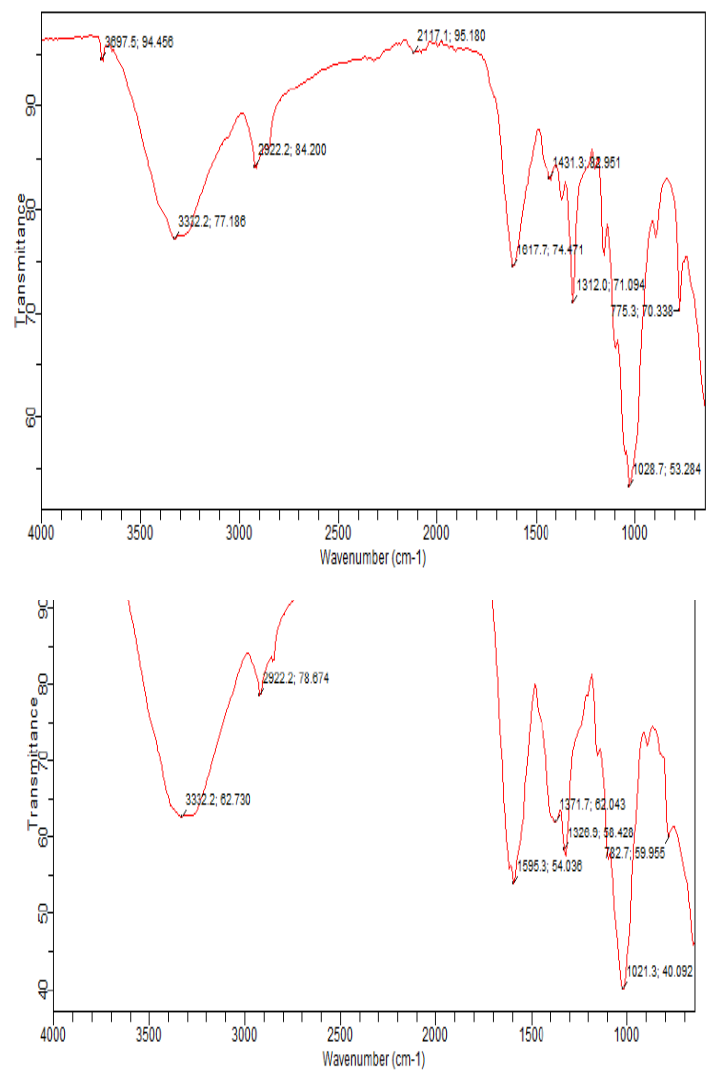

(b)

Gambar 8. (a) Spektrum FTIR batang pisang sebelum delignifikasi 
(b) Spektrum FTIR batang pisang sesudah delignifikasi

Puncak dengan intensitas panjang gelombang $3332,2 \mathrm{~cm}-1$ pada batang pisang menunjukkan gugus $-\mathrm{OH}$.

Gugus -OH pada kisaran panjang gelombang tersebut menunjukkan adanya ikatan hydrogen intramolekular dan merupakan gugus utama pada selulosa, karena selulosa merupakan rantai panjang dari $\beta$ glukosa (Lestari dkk, 2014).

Besarnya persen transmittance gugus $(\mathrm{OH})$ pada hasil analisis FTIR menunjukkan daya serap bahan terhadap air (Manalu, 2013). Gugus $\mathrm{C}=\mathrm{C}$ stretching vibration merupakan karakteristik dari kerangka lignin yang muncul disekitar 1500-1700cm-1. Puncak pada bilangan gelombang $1300 \mathrm{~cm}-1$ berhubungan dengan gugus $\mathrm{C}=\mathrm{O} \quad$ stretching vibrationyang melambangkan adanya kehadiran hemiselulosa.

\section{KESIMPULAN DAN SARAN}

Dari hasil proses delignifikasi batang pisang dengan pelarut asam formiat dengan menggunakan konsentrasi 70\%-berat selama 180 menit didapatkan kadar selulosa tertinggi sebesar 59,55\%.

Hasil analisis dengan menggunakan FTIR dan SEM menunjukan bahwa proses delignifikasi dengan menggunakan pelarut organik asam formiat dapat digunakan untuk memisahkan ikatan lignoselulosa, Dari hasil karakterisasi SEM terlihat perbedaan permukaan setelah dilakuan proses delignifikasi yaitu permukaan bahan yang semula rapat terliat renggan.

Adapun saran yang diberikan ialah untuk kedepannya Perlu dilakukan pengembangan lebih lanjut untuk mengetahui pengaruh penggunaan katalis $\mathrm{H} 2 \mathrm{O} 2$ dan variasi suhu pretreatment untuk meningkatkan yield selulosa.

\section{DAFTAR PUSTAKA}

Asparani, Monica. (2013). "Pengaruh Waktu Pemasakan Terhadap Pembuatan Pulp Pisang Menggunakan Proses Acetosoly”. Politeknik Negeri Sriwijaya, Palembang.

Dewi Tri Kurnia, Ariza Wulandari, Romi. (2009). "Pengaruh Temperatur, Lama Pemasakan, Dan Konsentraasi Etanol Pada Pembuatan Pulp Berbahan Baku Jerami Padi Dengan Larutan Pemasak $\mathrm{NaOH}$ - Etanol”. Jurnal Teknik Kimia, No. 3 Vol. 16.

Enny K. Artati, Ahmad Effendi, Tulus Haryanto. (2009). "Pengaruh Konsentrasi Larutan Pemasak Pada Proses Delignifikasi Eceng Gondok Dengan Proses Organosolv". Ekuilibrium, 8 (1).pp. 25 - 28.

Fatmayati, Nur Asma Deli. (2017). "Delignifikasi Batang Sawit Nonproduktif secara Organosolv dengan Asam Formiat”. Industria Jurnal Teknologi dan Manajemen Agroindustri., 6(3):113-118.

Hussain Intezar, Omer Mukhtar Tarar. (2014). "Pulp and Paper Making by using Waste Banana Stem”. Journal of Modern Science and Technology Vol. 2. No. 2. September 2014 Issue. Pp.36-40

Idi, A., Mohamad, S.E., 2011. "Bioethanol from second generation feedstock (lignocellulosic biomass)". Interdisciplinary Journal of Contemporary Research in Business, 3 (8), pp. 919-935. 
Kham L., Bigot Y. L., Delmas M., Avignon G., (2005), "Delignification of Wheat Straw Using A Mixture of Carboxylic Acids and Peroxoacids", Industrial Crops and Products An Internasional Journal, 21: 9-15.

Lestari. P, T.N. Hidayati, S. H. Indah, D. W. Marseno. (2014). "Pengembangan Teknologi Pembuatan Biopolimer Bernilai Ekonomi Tinggi dari Limbah Tanaman Jagung (Zea mays) untuk Industri Makanan : CMC (Carboxymethyl Cellulose)". EProceeding Pimnas PKM-P 2013.

Manalu, Santika dan Darni, Yuli. (2013). Pengaruh konsentrasi Plasticizer Terhadap Karakteristik Material Bioplastik Yang Ramah Lingkungan. ITB. Bandung.

Muharni Tuo. (2016). "Kandungan Hemselulosa, Selulosa dan Lignin Silase Pakan Lengkap Berbahan Utama Batang Pisang (Musa Paradisiaca) Dengan Lama Inkubasi Yang Berbeda". Fakultas Pertanian Universitas Hasanuddin. Makasar.

Muladi, S. (2013). Diktat Kuliah TeknologiKimia Kayu Lanjutan. Fakultas Kehutanan. Universitas Mulawarman: Samarinda.

Mosier N, Wyman C, Dale B, Elander R, Lee YY, Holtzapple M, dan Ladisch M.. (2005). "Features of promising technologies for pretreatment of lignocellulosic biomass". Bioresource technology, 96(6): 673-686.
Murni. R, Suparjo, Akmal dan B.L. Ginting. (2008). "Teknologi Pemanfaatan Limbah untuk Pakan". Fakultas Peternakan. Universitas Jambi. Jambi.

Idi, A., Mohamad, S.E., (2011). "Bioethanol from second generation feedstock (lignocellulosic biomass)". Interdisciplinary Journal of Contemporary Research in Business, 3 (8), pp. 919-935.

Murni. R, Suparjo, Akmal dan B.L. Ginting. (2008). "Teknologi Pemanfaatan Limbah untuk Pakan”. Fakultas Peternakan. Universitas Jambi. Jambi.

Parwati Cyrilla Indri dan Purnawan. (2014). "Pembuatan Pulp dari Serat Aren (Arenga pinnata) dengan Proses Nitrat Soda". Prosiding Seminar Nasional Aplikasi Sains dan Teknologi.

Pradana M. Adtya., Hosta Ardhyananta dan Moh. Farid. (2017). "Pemisahan Selulosa dari Lignin Serat Tandan Kosong Kelapa Sawit dengan Proses Alkalisasi untuk Penguat Bahan Komposit Penyerap Suara". Jurnal Teknik ITS Vol.6, No.2. ISSN: 23373539.

Kementrian Pertanian. (2014). ISSN $1907-$ 1507 : Outlook Komoditi Pisang. Pusat Data dan Sistem Informasi Pertanian

Rahman, H., (2006). Pembuatan Pulp dari Batang Pisang Uter (Musa paradisiacal Linn. var uter) Pascapanen dengan Proses Soda. Yogyakarta : Fakultas Kehutanan Universitas Gadjah Mada. 
Santi R. K., D. Fatmasari, S. D. Widyawati, dan W. P. S. Suprayogi. (2012). "Kualitas dan Nilai Kecernaan In Vitro Silase Batang Pisang (Musa paradisiaca) dengan Penambahan Beberapa Akselerator". Tropical Animal Husbandry Vol. 1 (1), 15-23. ISSN 2301-9921.

Sherly Oktarizona, Zulfansyah, Zuchra Helwani. (2016). "Pengaruh Kondisi Proses Terhadap Yield dan Kadar Lignin Pulp pada Fraksionasi Rumput Perimping dalam Media Asam Formiat”. Jom FTEKNIK Vol. 3 No. 1 2016.

Suharyani. (2012). "Limbah Pelepah Pisang (Musa Paradisiaca) Sebagai Alternatif Bahan Dinding Kedap Suara”. Jurnal Sinektika. 13 (1): 105111.

Sumada, K., Tamara, P. E., dan Alqani, F. (2011). "Isolation Study of Efficient $\alpha$ Cellulose from Waste Plant Stem Manihot esculenta crantz". Jawa Timur: UPN "Veteran". Jurnal Teknik Kimia Vol.5, No.2, April 2011.

Sun, J.X., Sun, X.F., Zhao, H. and Sun, R.C., (2004). "Isolation and characterization of cellulose from sugarcane bagasse". Polymer Degradation and Stability, 84, pp. 331339.

Susy Yunita Prabawati, Abdul Gani Wijaya. (2008). "Pemanfaatan Sekam Padi dan Pelepah Pohon Pisang Sebagai Bahan Alternatif Pembuat
Kertas Berkualitas". Jurnal Aplikasi Ilmu-Ilmu Agama, Vol. IX, No. 44 - 56.

Zhao X, Cheng K, dan Liu D. (2009). "Organosolv pretreatment of lignocellulosic biomass for enzymatic hydrolysis". Applied microbiology and biotechnology, 82(5): 815-827.

Zulfansyah, Maulvi, Sani Ikmal, Muhamad Iwan Fermi. (2011). "Pembuatan Pulp Semi Mekananis dari Batang Jagung dengan Ekstrak Abu Tandan Kosong Sawit”. Jurnal Teknik Kimia Universitas Riau. Pekanbaru. 
